\title{
Dry matter accumulation and mineral nutrition of arracacha in response to nitrogen fertilization
}

\author{
Luis Augusto Magolbo(1), Ezequiel Lopes do Carmo(2), Emerson Loli Garcia(1), \\ Adalton Mazetti Fernandes ${ }^{(1)}$ and Magali Leonel(1)
}

\begin{abstract}
(1)Universidade Estadual Paulista Júlio de Mesquita Filho, Centro de Raízes e Amidos Tropicais, Rua José Barbosa de Barros, no 1.780, CEP 18610-307 Botucatu, SP, Brazil. E-mail: Imagolbo@gmail.com, emerson.cerat@gmail.com, adalton@cerat.unesp.br, mleonel@cerat.unesp.br ${ }^{(2)}$ Instituto Federal de Educação, Ciência e Tecnologia de Mato Grosso, Campus de Campo Novo do Parecis, BR MT 235, Km 12, s/no, CEP 78360-000 Campo Novo do Parecis, SP, Brazil. E-mail: ezequielcerat@gmail.com
\end{abstract}

\begin{abstract}
The objective of this work was to evaluate the effect of nitrogen fertilization on the growth and yield of arracacha (Arracacia xanthorrhiza), as well as on the plant's nutrient uptake, distribution, and removal. The experiment was carried out in a typical Oxisol, with sandy texture. A randomized complete block design was used, with four replicates. The treatments consisted of five $\mathrm{N}$ rates: $0,50,100,200$, and $400 \mathrm{~kg} \mathrm{ha}^{-1}$. The plots were composed of three 8-m-length rows, spaced at $0.60 \mathrm{~m}$ between rows and $0.40 \mathrm{~m}$ between plants. The plants were harvested after an 8-month cycle. Nitrogen fertilization significantly increased the proportion of $\mathrm{N}$ and $\mathrm{S}$ accumulated in stems, and of $\mathrm{Ca}, \mathrm{Mg}, \mathrm{Fe}$, and $\mathrm{Mn}$ in leaves. $\mathrm{N}$ supply increased $\mathrm{Zn}$ distribution to stems and leaves, whereas high $\mathrm{N}$ rates increased $\mathrm{Cu}$ allocation to stems more than to the rootstock. High $\mathrm{N}$ rates increase plant dry matter (DM) production and nutrient uptake and removal, but do not result in the greatest yield due to the greater development of leaves and stems, and to the lower allocation of DM in storage roots.
\end{abstract}

Index terms: Arracacia xanthorrhiza, dry matter allocation, nutrient accumulation, nutrient concentration, storage root.

\section{Acúmulo de matéria seca e nutrição mineral da mandioquinha-salsa em resposta à adubação nitrogenada}

Resumo - O objetivo deste trabalho foi avaliar o efeito da adubação nitrogenada no crescimento e na produtividade de mandioquinha-salsa (Arracacia xanthorrhiza), bem como na absorção, na distribuição e na exportação de nutrientes pela planta. O experimento foi conduzido em Latossolo Vermelho distrófico, de textura arenosa. Utilizou-se o delineamento experimental de blocos ao acaso, com quatro repetições. Os tratamentos consistiram de cinco doses de N: 0, 50,100, 200 e $400 \mathrm{~kg} \mathrm{ha}^{-1}$. As parcelas foram compostas por três fileiras de plantas de $8 \mathrm{~m}$ de comprimento, no espaçamento de $0,60 \mathrm{~m}$ entre fileiras e $0,40 \mathrm{~m}$ entre plantas. A colheita das plantas foi realizada após ciclo de 8 meses. A adubação nitrogenada aumentou significativamente a proporção de $\mathrm{N}$ e $\mathrm{S}$ acumulada nos rebentos, e de $\mathrm{Ca}, \mathrm{Mg}$, Fe e Mn nas folhas. A aplicação de $\mathrm{N}$ aumentou a distribuição de $\mathrm{Zn}$ para rebentos e folhas, enquanto altas doses de $\mathrm{N}$ aumentaram mais a alocação de $\mathrm{Cu}$ para os rebentos do que para a coroa. Altas doses de $\mathrm{N}$ aumentam a produção de matéria seca (MS) das plantas e a absorção e a exportação de nutrientes, mas não acarretam maior produtividade, em razão do maior desenvolvimento das folhas e dos rebentos e da menor alocação de MS nas raízes tuberosas.

Termos para indexação: Arracacia xanthorrhiza, alocação de matéria seca, acúmulo de nutrientes, teor de nutrientes, raízes tuberosas.

\section{Introduction}

Arracacha (Arracacia xanthorrhiza Bancroft) is a commonly-grown vegetable in Brazil, mainly in the South, Southeast (Heredia Zárate et al., 2009), and Center-West regions (Sediyama et al., 2009). The plant's storage roots have great social and economic importance for producing regions, as well as high nutritional value, due to their richness in carbohydrates, minerals, and vitamins (Rocha et al., 2008; Pádua, 2010), greater starch content, and high digestibility (Rocha et al., 2008; Nunes et al., 2010). The area planted to arracacha has increased in several regions of the country in recent years (Portz et al., 2006). 
However, because of this crop's high rusticity and lack of demand for fertilizers and agricultural chemicals (Sediyama et al., 2008), studies on its mineral nutrition are still incipient, which makes it difficult for precise recommendations on fertilizer use in different sites and management conditions (Costa, 2000; Portz et al., 2006).

Among the nutrients required by arracacha plants, potassium is the most absorbed (Furlani et al., 1978; Portz et al., 2006), but phosphorus leads to greater increases in root yield (Silva et al., 1966). Although nitrogen is the second nutrient with highest uptake by the crop (Furlani et al., 1978; Portz et al., 2006), there is still little information on the best $\mathrm{N}$ application rate, which is important since this nutrient may either increase or decrease storage root yield.

Application rates above $50 \mathrm{~kg} \mathrm{ha}^{-1} \mathrm{~N}$ caused a reduction in this crop's root yield (Silva et al., 1966), and the excessive supply of this nutrient resulted in a negative response in storage root formation (Mesquita Filho et al., 1996; Portz et al., 2003). However, in a study carried out in an Ultisol, an increase in storage root yield was observed up to the application rate of $135 \mathrm{~kg} \mathrm{ha}^{-1} \mathrm{~N}$ (Del Valle Júnior et al., 1995). These results show that the response of arracacha to nutrient application is still a matter of debate, due to the different responses observed in different soil classes and regions. Therefore, it becomes difficult to define the best $\mathrm{N}$ application rates for the crop to maximize storage root yield, especially in sandy soils, in which $\mathrm{N}$ losses by leaching may be higher, as observed in other crops (Lopes et al., 2013).

Although high $\mathrm{N}$ application rates promote greater growth, particularly in shoots, supplying this nutrient may affect the amounts of nutrient uptake by the plant. In the case of arracacha, nutrient accumulation may be affected by crop management conditions (Portz et al., 2006). Moreover, the effects of N supply on nutrient uptake, dry matter (DM), and allocation to the storage roots are not well understood. Therefore, knowledge of $\mathrm{N}$ response of arracacha grown in sandy soil is essential in order to assist $\mathrm{N}$ fertilization management.

The objective of this work was to evaluate the effect of nitrogen fertilization on the growth and yield of arracacha (Arracacia xanthorrhiza), as well as on the plant's nutrient uptake, distribution, and removal, grown in sandy soil.

\section{Materials and Methods}

A field experiment was carried out in the municipality of São Manuel, in the state of São Paulo, Brazil ( $48^{\circ} 34^{\prime} \mathrm{W}, 22^{\circ} 46^{\prime} \mathrm{S}$, at $740 \mathrm{~m}$ above sea level), on a Latossolo Vermelho distrófico (Santos et al., 2006), an Oxisol, according to Soil Survey Staff (2010), with $104 \mathrm{~g} \mathrm{~kg}^{-1}$ clay, $24 \mathrm{~g} \mathrm{~kg}^{-1}$ silt, and $872 \mathrm{~g} \mathrm{~kg}^{-1}$ sand. Data on rainfall and temperature during the experimental period are presented in Table 1.

Before setting up the experiment, the chemical properties of the surface layer $(0-0.20 \mathrm{~m})$ were determined. The soil characteristics were as follows: $10 \mathrm{~g} \mathrm{dm}^{-3}$ organic matter; $\mathrm{pH}\left(\mathrm{CaCl}_{2}\right) 5.4 ; 10 \mathrm{mg} \mathrm{dm}^{-3}$ $\mathrm{P}$ (resin); 1.0, 7.0, 3.0, and $14 \mathrm{mmol}_{\mathrm{c}} \mathrm{dm}^{-3} \mathrm{~K}, \mathrm{Ca}$, $\mathrm{Mg}$, and $\mathrm{H}+\mathrm{Al}$, respectively; base saturation of $43 \%$;

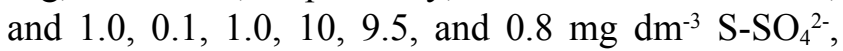
$\mathrm{B}, \mathrm{Cu}, \mathrm{Fe}, \mathrm{Mn}$, and $\mathrm{Zn}$, respectively. For planting of arracacha, the soil was prepared by conventional tillage with a plow and a rotary hoe. After soil preparation, dolomitic limestone was applied at a rate necessary for raising base saturation to $80 \%$, according to the recommendations for the crop (Monteiro \& Peressin, 1997). Dolomitic limestone was then incorporated into the soil with a rotary hoe.

The experiment was set up in a randomized complete block design, with four replicates. Treatments consisted of five $\mathrm{N}$ rates: $0,50,100,200$, and $400 \mathrm{~kg} \mathrm{ha}^{-1}$. The plots were composed of three 8-m-length rows of plants, spaced at $0.60 \mathrm{~m}$ between rows and $0.40 \mathrm{~m}$ between plants in the row. Only the central 6-m-length row of plants was considered for evaluation, with $1.0 \mathrm{~m}$ left on each side of the plant row. On April $4^{\text {th }}, 2013$, at 60 days after limestone application, $200 \mathrm{~kg} \mathrm{ha}^{-1}$ $\mathrm{P}_{2} \mathrm{O}_{5}$ and $\mathrm{K}_{2} \mathrm{O}$, as well as $50 \%$ of the $\mathrm{N}$ application rate stipulated for each treatment, were applied. The fertilizer N- $\mathrm{P}_{2} \mathrm{O}_{5}-\mathrm{K}_{2} \mathrm{O}(00-10-10)$ was used as a source of $\mathrm{P}$ and $\mathrm{K}$, and urea as a source of $\mathrm{N}$. The fertilizers were subsequently incorporated with a rotary hoe.

Arracacha, cultivar Amarela of Senador Amaral, was planted using selected healthy plantlets, pre-rooted in trays for 30 days. For pre-rooting, plantlets were initially immersed in $5 \%(\mathrm{v} / \mathrm{v})$ sodium hypochlorite solution for $10 \mathrm{~min}$, bevel cut, and placed in the substrate trays. Planting was done at a spacing of $0.60 \mathrm{~m}$ between rows and of $0.40 \mathrm{~m}$ between plants in the row.

The remaining $50 \%$ of the $\mathrm{N}$ fertilization rates established for each treatment were split into two 
applications at 30 and 60 days after planting. The $\mathrm{N}$ source used in top-dressing fertilization was urea. Weed control was made manually when necessary. Irrigation and plant health measures were carried out according to recommendations for the crop in the region.

Harvest was made after an 8-month cycle, by collecting eight whole plants from the useful area of each plot (one 6-m-length row of plants). At this moment, plant density was also determined. After harvest, the plants were separated into leaves, stems, rootstock, and storage roots and then washed. The fresh storage roots were weighed to determine total yield, and all plant parts were dried in a forced-air circulation oven, at $65^{\circ} \mathrm{C}$, for 96 hours. After that, the samples were weighed and, together with data on DM of eight plants and on plant density, were used to calculate the amounts of DM accumulated in each plant part and in the whole plant. Allocation of DM to storage roots was determined by the relation between amounts of DM accumulated in storage roots and in the whole plant (Otsubo et al., 2009).

Samples were ground in a Willey mill, and nutrient concentrations of $\mathrm{N}, \mathrm{P}, \mathrm{K}, \mathrm{Ca}, \mathrm{Mg}, \mathrm{S}, \mathrm{B}, \mathrm{Cu}, \mathrm{Fe}, \mathrm{Mn}$, and $\mathrm{Zn}$ were determined according to Malavolta et al. (1997). The amounts of accumulated nutrients in each part of the plant and in the whole plant were calculated based on nutrient concentrations and DM accumulation. Nutrient removal was determined by the ratio between storage root yield and nutrient concentration in roots.

The data were subjected to analysis of variance. Effects of $\mathrm{N}$ application rates were evaluated by regression analysis, using the SigmaPlot software, version 10.0 (Chicago, IL, USA).

Table 1. Monthly rainfall and average monthly temperatures from April to December 2013 in the experimental area, in the municipality of São Manuel, in the state of São Paulo, Brazil.

\begin{tabular}{lcc}
\hline Month & Monthly rainfall $(\mathrm{mm})$ & Average temperature $\left({ }^{\circ} \mathrm{C}\right)$ \\
\hline April & 125.9 & 22.0 \\
May & 96.6 & 20.3 \\
June & 115.4 & 17.9 \\
July & 57.3 & 17.1 \\
August & 0.0 & 18.5 \\
September & 88.0 & 20.0 \\
October & 107.3 & 20.9 \\
November & 44.6 & 22.7 \\
December & 64.8 & 24.5 \\
\hline
\end{tabular}

\section{Results and Discussion}

Nitrogen fertilization increased total DM of arracacha plants up to the rate of $266 \mathrm{~kg} \mathrm{ha}^{-1} \mathrm{~N}$, which resulted in an increase of $78 \%$ in DM production (Figure 1). In leaves and stems, there was an increase in the accumulation of DM up to the rates of 335 and $331 \mathrm{~kg} \mathrm{ha}^{-1} \mathrm{~N}$, i.e., rates greater than those of 258 and $175 \mathrm{~kg} \mathrm{ha}^{-1} \mathrm{~N}$, respectively, that led to the maximum accumulation of DM in the rootstock and storage roots. This means that high $\mathrm{N}$ rates are a greater stimulus for the growth of leaves and stems than for storage structures, which was also observed in sweet potato [Ipomoea batatas (L.) Lam] (Oliveira et al., 2006). Regardless of $\mathrm{N}$ fertilization, the greatest $\mathrm{DM}$ accumulations occurred in storage roots and the lowest ones in leaves. More than $50 \%$ of plant DM was composed of storage roots (Figure 1), which indicates that storage roots act as preferential sinks for photoassimilates in arracacha plants (Portz et al., 2006; Torales et al., 2014).

In storage roots, the accumulation and allocation of DM were reduced with application rates from 100 to $175 \mathrm{~kg} \mathrm{ha}^{-1} \mathrm{~N}$, but in other parts of the plant the reduction in DM accumulation and allocation occurred with higher $\mathrm{N}$ rates (Figure 1). This indicates that excessive $\mathrm{N}$ application rates decrease storage root growth and the harvest index, favoring the growth of the vegetative part of the plant, as reported in other tuberous species (Oliveira et al., 2006; Coelho et al., 2010). Therefore, the use of treatments that promote aboveground development does not necessarily result in improvement in storage root production. However, other studies have shown that taller, more thriving plants, with greater leaf area and height, produce greater amounts of marketable storage roots (Graciano et al., 2006; Portz et al., 2006), and that there is a positive correlation between marketable root yield and the DM of propagules (rootstock + stems) (Portz et al., 2006).

The total yield of storage roots had an increase of $70 \%$ up to $165 \mathrm{~kg} \mathrm{ha}^{-1} \mathrm{~N}$, when it reached $21.3 \mathrm{Mg} \mathrm{ha}^{-1}$ (Figure 1). However, Portz et al. (2006) did not find a significant increase in storage root yield with the application of up to $120 \mathrm{~kg} \mathrm{ha}^{-1} \mathrm{~N}$. Despite the positive $\mathrm{N}$ response of arracacha obtained in the present study, rates lower than $100 \mathrm{~kg} \mathrm{ha}^{-1} \mathrm{~N}$ are usually recommended for $\mathrm{N}$ fertilization of this crop (Monteiro \& Peressin, 1997; Filgueira, 2008). The obtained storage root yield 
was higher than the national average of $9.2 \mathrm{Mg} \mathrm{ha}^{-1}$ (Sediyama et al., 2009) and than the average yield of some Brazilian states of 10 to $15 \mathrm{Mg} \mathrm{ha}^{-1}$ (Heredia Zárate et al., 2008).
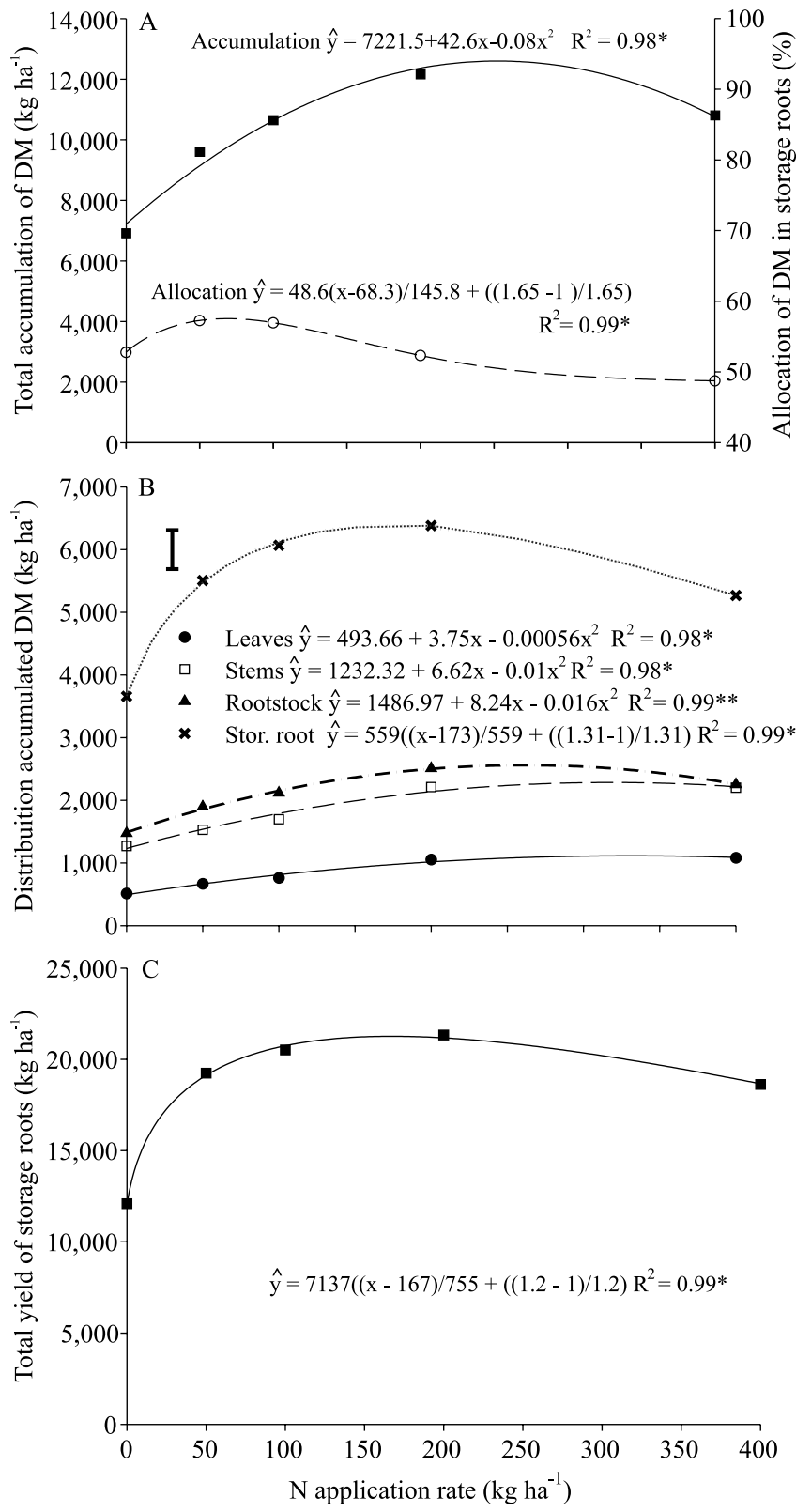

Figure 1. Total accumulation of DM in plant and allocation of DM in storage roots (A), distribution of accumulated DM among plant parts (B), and total yield of storage roots (C) in arracacha (Arracacia xanthorrhiza) plants as a function of $\mathrm{N}$ application rates. $*$ and $* *$ significant at 5 and $1 \%$ probability, respectively. Vertical bars indicate the LSD value at $5 \%$ probability.
The total amounts of $\mathrm{N}, \mathrm{Ca}, \mathrm{Mg}$, and $\mathrm{S}$ accumulated in the arracacha plants increased up to rates from 300 to $350 \mathrm{~kg} \mathrm{ha}^{-1} \mathrm{~N}$, i.e., rates greater than those that brought about maximum DM production (Figures 1, 2, and 3). Maximum accumulation of $\mathrm{K}$ and $\mathrm{P}$ was obtained at lower $\mathrm{N}$ rates, which varied from 221 to $275 \mathrm{~kg} \mathrm{ha}^{-1}$ (Figure 2). Nitrogen fertilization increased the uptake of $\mathrm{N}$ and $\mathrm{S}$ in about $110 \%$; of $\mathrm{K}$ and $\mathrm{Mg}$ in 64 to $56 \%$; and of $\mathrm{P}$ and $\mathrm{Ca}$ from 78 to $81 \%$ (Figures 2 and 3 ). Nitrogen fertilization increases plant DM production and the crop's demands for nutrients. However, greater nutrient accumulation by arracacha does not always result in greater storage root yield, since $\mathrm{N}$ excess increases the growth of the vegetative part of the plant and decreases the growth of and DM allocation in storage roots; this may cause an increase in nutrient uptake, but without significantly increasing storage root yield (Figures 1, 2, and 3).

Maximum macronutrient uptake in response to $\mathrm{N}$ fertilization was of: $123,32,233,43.5,15.6$, and $16.7 \mathrm{~kg} \mathrm{ha}^{-1} \mathrm{~N}, \mathrm{P}, \mathrm{K}, \mathrm{Ca}, \mathrm{Mg}$, and $\mathrm{S}$, respectively (Figures 2 and 3), showing great nutrient demands by the arracacha crop. Portz et al. (2006) found values of macronutrient uptake per area - determined by plant population and nutrient accumulation per plant - greater than those reported in the present study, possibly due to the higher DM accumulation in the evaluated plants.

In regard to nutrient uptake and distribution, $\mathrm{N}$ application increased the amounts of accumulated macronutrients in practically all parts of the arracacha plants. Regardless of $\mathrm{N}$ fertilization, storage roots were always the main sinks for $\mathrm{P}$ and $\mathrm{K}$ (Figures 2 and $3)$. However, storage roots were not the main sinks for $\mathrm{N}, \mathrm{Ca}, \mathrm{Mg}$, and $\mathrm{S}$, which is in agreement with the findings of Portz et al. (2006), who observed that propagules accumulate greater amounts of nutrients than storage roots. In other tuberous species, such as sweet potato and potato (Solanum tuberosum L.), the storage organ (storage roots and tubers) was also not the main sink for all the macronutrients (Echer et al., 2009; Fernandes et al., 2011). At lower $\mathrm{N}$ rates, the amounts of $\mathrm{N}, \mathrm{Ca}$, and $\mathrm{Mg}$ accumulated in all plant parts were similar, whereas the accumulation of $\mathrm{S}$ was greater in the storage roots. At greater $\mathrm{N}$ rates, storage roots and stems became the main sinks for $\mathrm{N}$ and $\mathrm{S}$, and the leaves accumulated the greatest amounts of $\mathrm{Ca}$; however, the greatest accumulations 
of $\mathrm{Mg}$ occurred in leaves and stems. This shows that $\mathrm{N}$ fertilization affects the uptake and distribution of these nutrients among the plant parts. Therefore, both in the presence and in the absence of $\mathrm{N}$ fertilization,
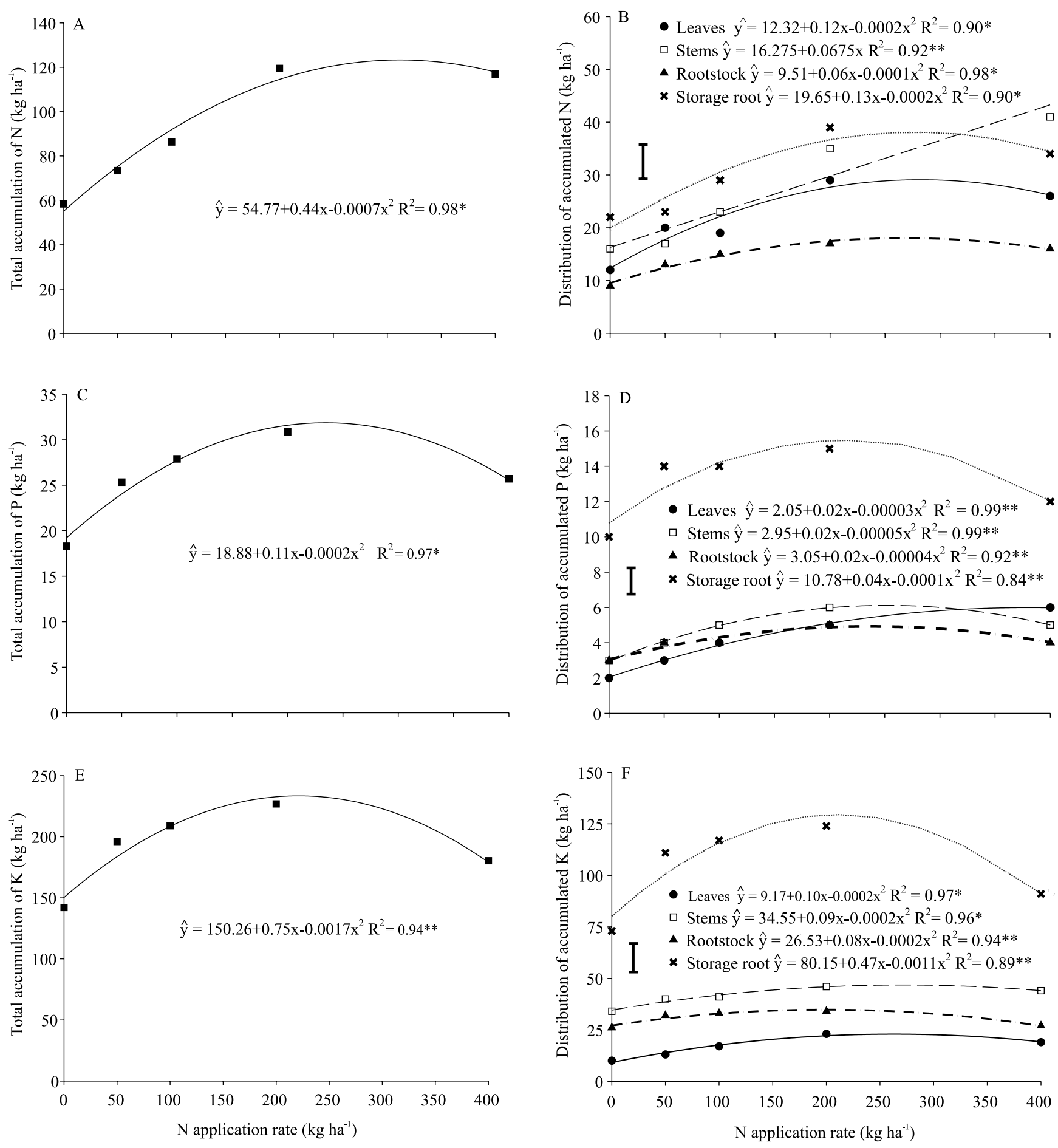

Figure 2. Total accumulation and distribution of the accumulated amounts of $N(A, B), P(C, D)$, and $K(E, F)$ in arracacha (Arracacia xanthorrhiza) plants as a function of $\mathrm{N}$ application rates. * and ** significant at 5 and $1 \%$ probability, respectively. Vertical bars indicate the LSD value at 5\% probability. 

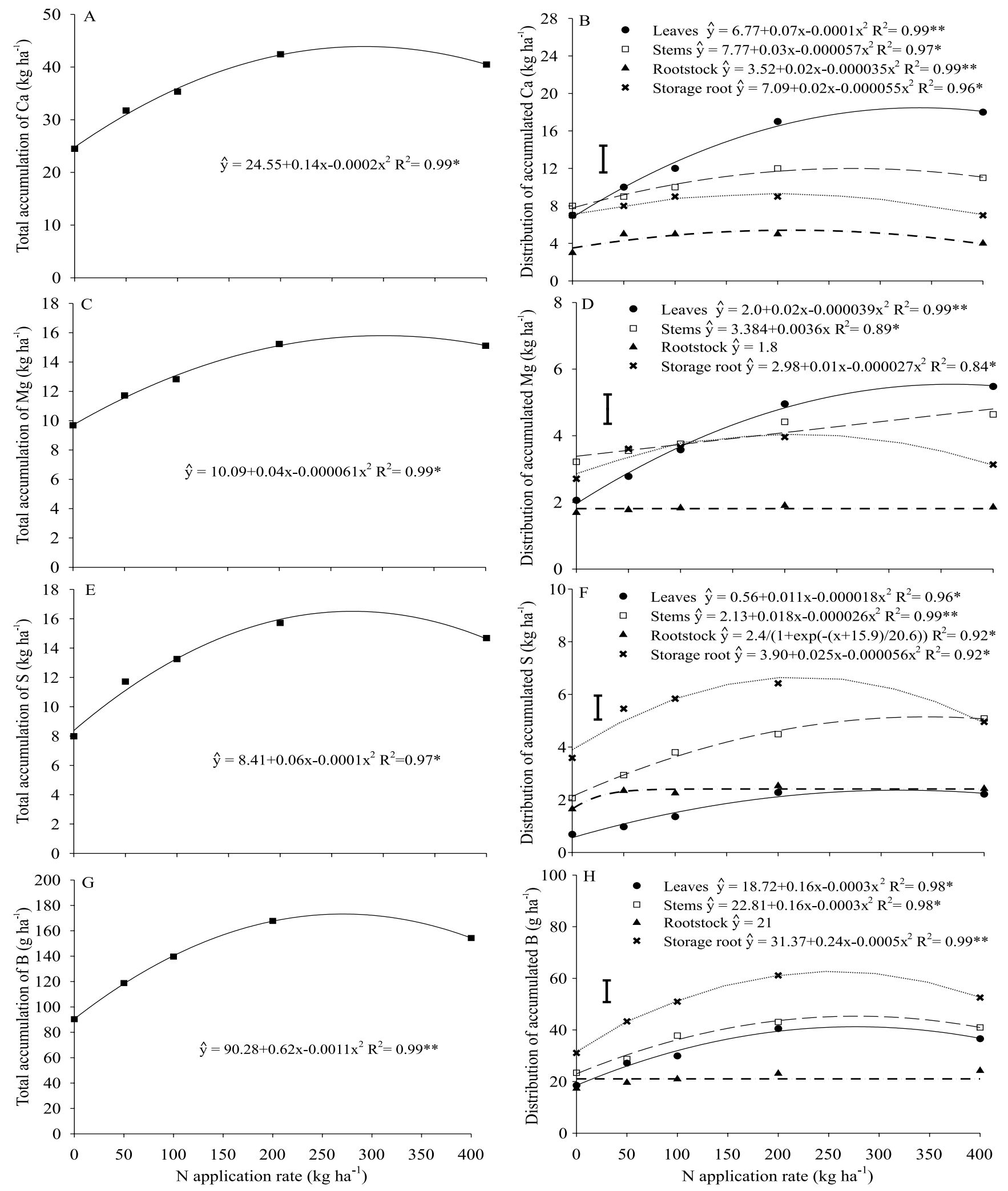

Figure 3. Total accumulation and distribution of the accumulated amounts of $\mathrm{Ca}(\mathrm{A}, \mathrm{B}), \mathrm{Mg}(\mathrm{C}, \mathrm{D}), \mathrm{S}(\mathrm{E}, \mathrm{F})$, and $\mathrm{B}(\mathrm{G}, \mathrm{H})$ in arracacha (Arracacia xanthorrhiza) plants as a function of $\mathrm{N}$ application rates. * and ** significant at 5 and $1 \%$ probability, respectively. Vertical bars indicate the LSD value at $5 \%$ probability. 
not all the macronutrients are accumulated in greater proportions in the propagules, when compared to storage roots. Despite this, Portz et al. (2006) found greater proportions of macronutrients accumulated in propagules.

In relation to micronutrients, $\mathrm{N}$ fertilization led to a linear increase in the total amounts of Mn uptake, whereas the maximum uptake of B and $\mathrm{Zn}$ occurred with $\mathrm{N}$ rates from 282 to $297 \mathrm{~kg} \mathrm{ha}^{-1}$ (Figures 3 and 4). For $\mathrm{Cu}$ and $\mathrm{Fe}$, the highest amounts were absorbed at lower $\mathrm{N}$ application rates, from 207 to $221 \mathrm{~kg} \mathrm{ha}^{-1}$ (Figure 4). $\mathrm{N}$ application increased the maximum amounts of $\mathrm{B}$, $\mathrm{Cu}, \mathrm{Fe}, \mathrm{Mn}$, and $\mathrm{Zn}$ taken up by arracacha in 92,88 , 70,143 , and $71 \%$, respectively (Figures 3 and 4). This means that $\mathrm{N}$ fertilization, providing for greater plant growth, increased this crop's nutritional demands for micronutrients.

Maximum micronutrient uptake in response to $\mathrm{N}$ fertilization was of: 173, 77, 2,055, 330, and $338 \mathrm{~g} \mathrm{ha}^{-1} \mathrm{~B}, \mathrm{Cu}, \mathrm{Fe}, \mathrm{Mn}$, and $\mathrm{Zn}$, respectively (Figures 3 and 4). Portz et al. (2006), in harvest carried out at 300 days, obtained Fe uptake values of 2,454 $\mathrm{g} \mathrm{ha}^{-1}$, similar to those of the present study; however, the amounts of $\mathrm{Cu}, \mathrm{Mn}$, and $\mathrm{Zn}$ taken up were much lower, of 15,57 , and $74 \mathrm{~g} \mathrm{ha}^{-1}$, respectively.

Nitrogen fertilization increased the accumulation of micronutrients and affected their distribution among plant parts (Figures 3 and 4). Excessive provision of $\mathrm{N}$ mainly reduced micronutrient accumulation in storage roots. At intermediate $\mathrm{N}$ application rates, storage roots were the main sinks for $\mathrm{B}$ and $\mathrm{Cu}$ in the plants, but at the lower $\mathrm{N}$ rates, the stems were the main sinks for $\mathrm{Fe}$ and $\mathrm{Mn}$; moreover, $\mathrm{Zn}$ accumulation in the rootstock, stems, and storage roots was similar but greater than in leaves. However, Portz et al. (2003) observed that, in addition to $\mathrm{Cu}, \mathrm{Fe}$ was also accumulated at greater amounts in storage roots, which did not occur in the present study. At higher $\mathrm{N}$ rates, the main sinks were: storage roots and stems for $\mathrm{B}$ and $\mathrm{Cu}$; stems and leaves for $\mathrm{Fe}$ and $\mathrm{Mn}$; and stems for $\mathrm{Zn}$. In sweet potato, high accumulations of $\mathrm{Cu}$ were also observed in storage roots, and of $\mathrm{Fe}$ and $\mathrm{Mn}$ in leaves and stems; however, the main sink for Zn were the leaves and not the storage roots (Echer et al., 2009), as observed in the present study for arracacha.
Nitrogen fertilization reduced $\mathrm{P}, \mathrm{K}, \mathrm{Ca}$, and $\mathrm{Mg}$ concentrations in storage roots, but did not affect $\mathrm{N}$ and $\mathrm{S}$ concentrations (Figure 5). However, $\mathrm{N}$ application increased the removal of all macronutrients up to $\mathrm{N}$ rates from 182 to $325 \mathrm{~kg} \mathrm{ha}^{-1}$, when removal reached the maximum values of $39,15.8,129,9.1,4.1$, and $6.7 \mathrm{~kg} \mathrm{ha}^{-1} \mathrm{~N}, \mathrm{P}, \mathrm{K}, \mathrm{Ca}, \mathrm{Mg}$, and $\mathrm{S}$, respectively. In sweet potato, for the yield of $36,5 \mathrm{Mg} \mathrm{ha}^{-1}$, crop nutrient removal by storage roots was around 129, 16, 81, 23, 7.4, and $9.6 \mathrm{~kg} \mathrm{ha}^{-1} \mathrm{~N}, \mathrm{P}, \mathrm{K}, \mathrm{Ca}, \mathrm{Mg}$, and $\mathrm{S}$ (Echer et al., 2009), i.e., values lower than those obtained in the present study only for $\mathrm{K}$.

Nitrogen fertilization increased $\mathrm{N}$ and $\mathrm{K}$ removal by $76 \%, \mathrm{~S}$ removal by $86 \%, \mathrm{P}$ and $\mathrm{Mg}$ removal from 52 to $65 \%$, and Ca removal only by $36 \%$ (Figure 5 ). The total yield of storage roots was increased by $70 \%$ in response to $\mathrm{N}$ fertilization, which shows that increases in yield by $\mathrm{N}$ fertilization do not increase the removal of all macronutrients in the same proportion. Fernandes et al. (2011) also observed that, in the potato crop, the removal of macronutrients was not directly related to tuber yield. However, Portz et al. (2006) obtained positive and significant correlations between marketable yield and the removal of all macronutrients in the arracacha crop.

B concentration in storage roots linearly increased with $\mathrm{N}$ fertilization, whereas $\mathrm{Cu}$ and $\mathrm{Fe}$ concentrations decreased (Figure 6). Mn concentrations were not affected by $\mathrm{N}$ fertilization, but $\mathrm{Zn}$ concentrations were reduced up to the application rate of $223 \mathrm{~kg} \mathrm{ha}^{-1} \mathrm{~N}$. Even so, the removal of all micronutrients increased with $\mathrm{N}$ application, due to the increases in storage root DM and yield (Figures 1 and 6). However, the maximum removal of $\mathrm{Cu}$ and $\mathrm{Fe}$ was obtained with $\mathrm{N}$ rates from 167 to $183 \mathrm{~kg} \mathrm{ha}^{-1}$, whereas for the other micronutrients, the maximum values of removal occurred at rates from 206 to $240 \mathrm{~kg} \mathrm{ha}^{-1} \mathrm{~N}$ (Figure 6). $\mathrm{N}$ application increased the removal of $\mathrm{B}$ by $105 \%$, of $\mathrm{Cu}$ and $\mathrm{Fe}$ by 60 to $65 \%$, and of $\mathrm{Mn}$ and $\mathrm{Zn}$ by 42 to $50 \%$.

$\mathrm{N}$ application brought about maximum removal of 63, 29, 387, 28, and $95 \mathrm{~g} \mathrm{ha}^{-1} \mathrm{~B}, \mathrm{Cu}, \mathrm{Fe}, \mathrm{Mn}$, and $\mathrm{Zn}$, respectively (Figure 6). Lower values for the removal of $\mathrm{Cu}, \mathrm{Fe}, \mathrm{Mn}$, and $\mathrm{Zn}$ were reported by Portz et al. (2006) for a much lower yield of $12 \mathrm{Mg} \mathrm{ha}^{-1}$. In general, $\mathrm{N}$ fertilization promoted an increase in nutrient uptake and a removal up to higher $\mathrm{N}$ application rates than those for maximum total yield of storage roots.

Pesq. agropec. bras., Brasília, v.50, n.8, p.669-680, ago. 2015 DOI: $10.1590 / \mathrm{S} 0100-204 \mathrm{X} 2015000800005$ 

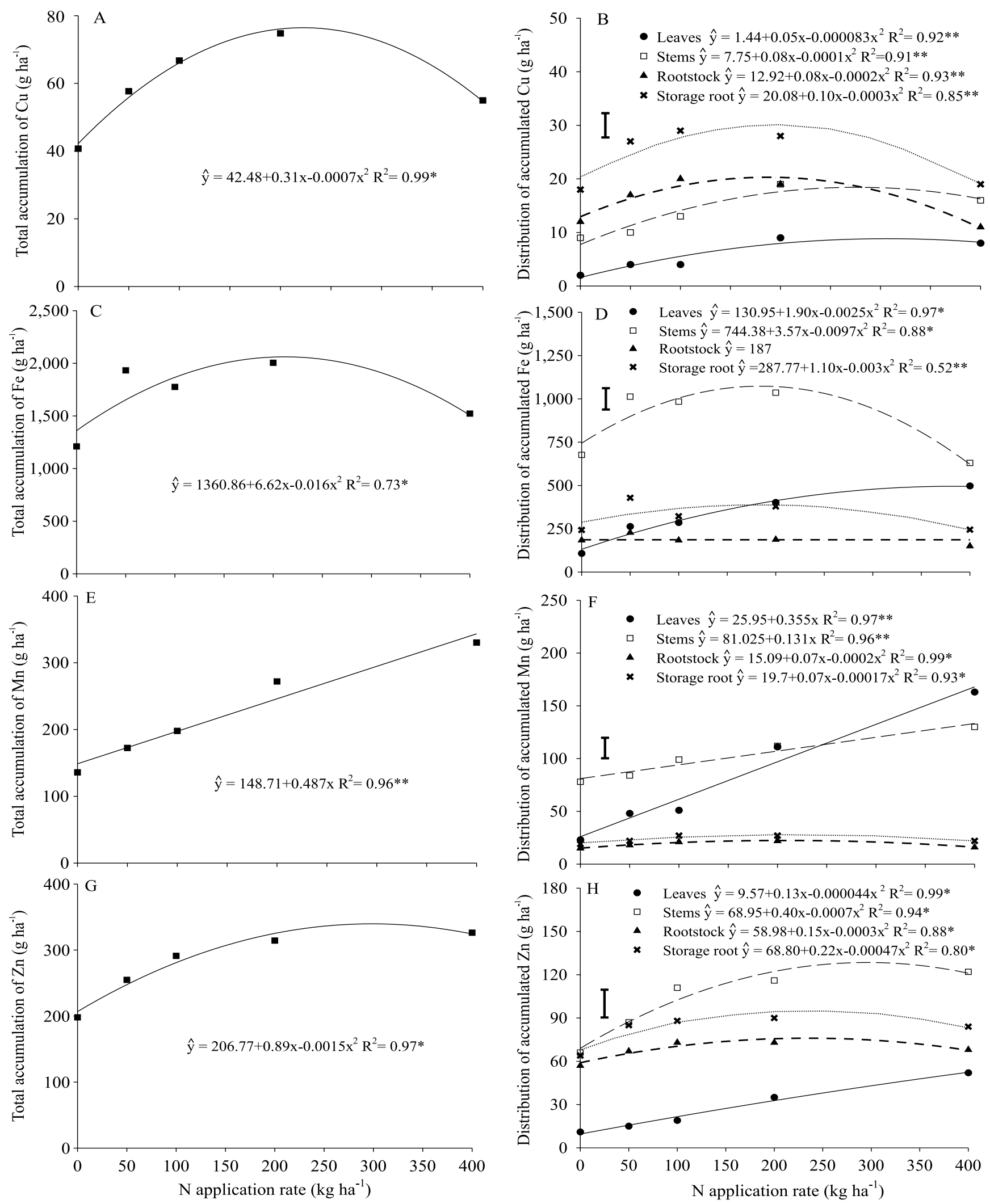

Figure 4. Total accumulation and distribution of the accumulated amounts of $\mathrm{Cu}(\mathrm{A}, \mathrm{B}), \mathrm{Fe}(\mathrm{C}, \mathrm{D}), \mathrm{Mn}(\mathrm{E}, \mathrm{F})$, and $\mathrm{Zn}(\mathrm{G}, \mathrm{H})$ in arracacha (Arracacia xanthorrhiza) plants as a function of $\mathrm{N}$ application rates. * and ** significant at 5 and $1 \%$ probability, respectively. Vertical bars indicate the LSD value at $5 \%$ probability. 

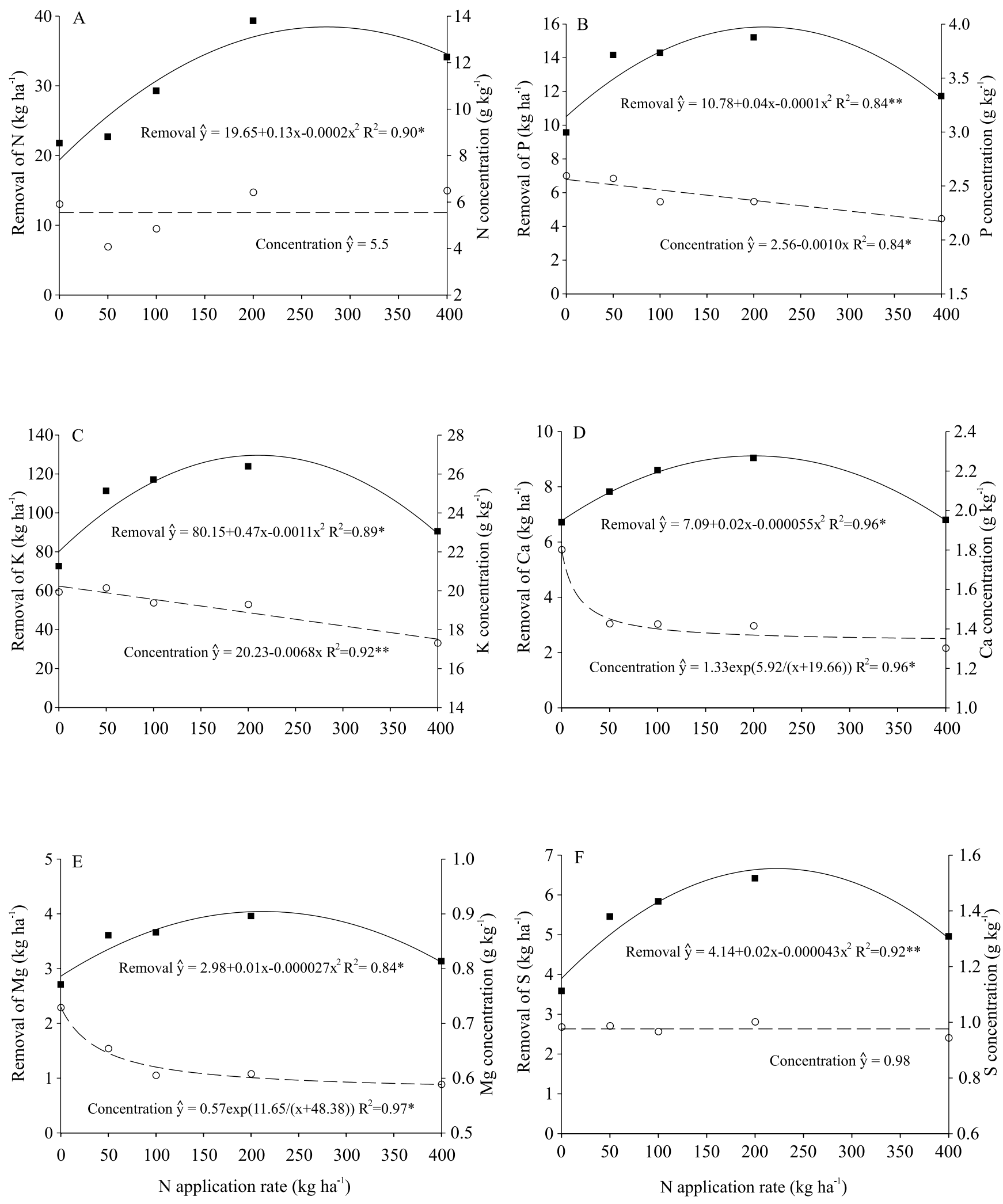

Figure 5. Concentration and removal of $\mathrm{N}(\mathrm{A}), \mathrm{P}(\mathrm{B}), \mathrm{K}(\mathrm{C}), \mathrm{Ca}(\mathrm{D}), \mathrm{Mg}(\mathrm{E})$, and $\mathrm{S}(\mathrm{F})$ by the storage roots of arracacha (Arracacia xanthorrhiza) plants as a function of $\mathrm{N}$ application rates. * and ** significant at 5 and $1 \%$ probability, respectively. 

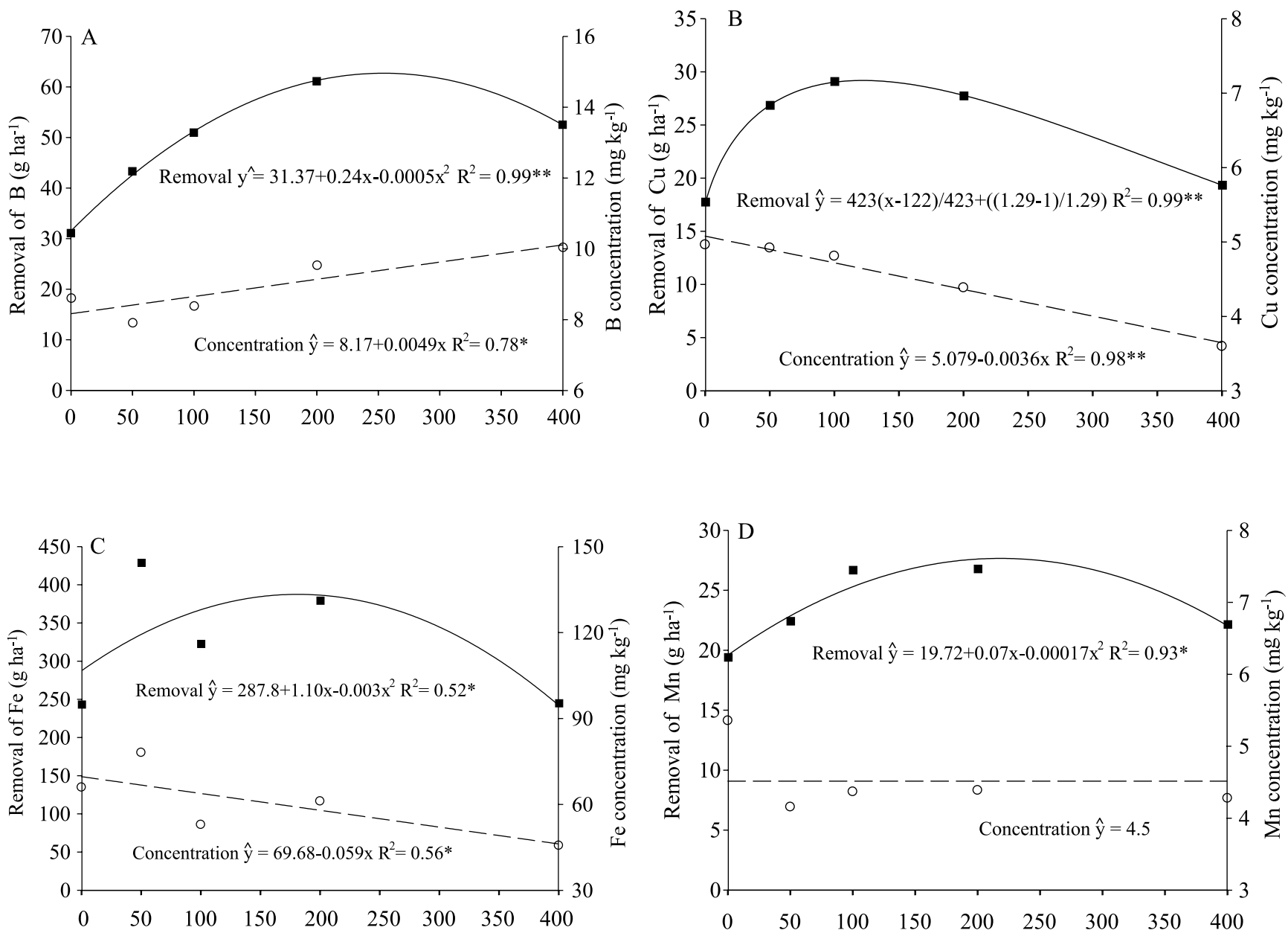

$\mathrm{N}$ application rate $\left(\mathrm{kg} \mathrm{ha}^{-1}\right)$

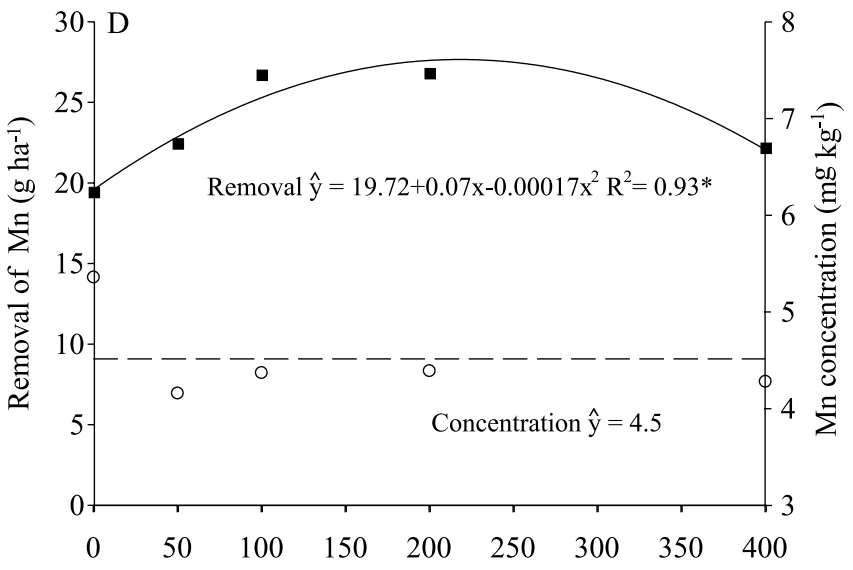

$\mathrm{N}$ application rate $\left(\mathrm{kg} \mathrm{ha}^{-1}\right)$

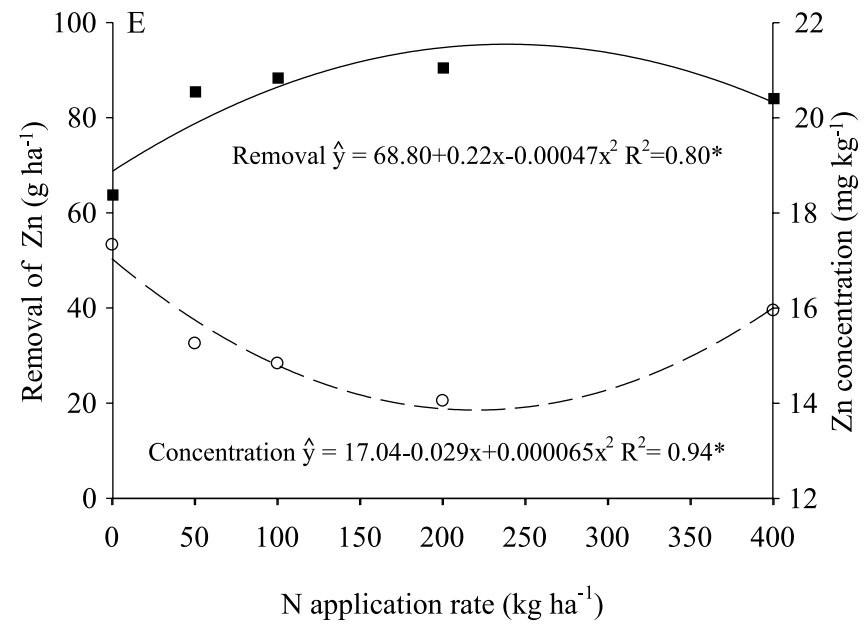

Figure 6. Removal and concentration of $\mathrm{B}(\mathrm{A}), \mathrm{Cu}(\mathrm{B}), \mathrm{Fe}(\mathrm{C}), \mathrm{Mn}(\mathrm{D})$, and $\mathrm{Zn}(\mathrm{E})$ by the storage roots of arracacha (Arracacia xanthorrhiza) plants as a function of $\mathrm{N}$ application rates. * and ** significant at 5 and $1 \%$ probability, respectively. 


\section{Conclusions}

1. Fertilization with high $\mathrm{N}$ rates increase plant dry matter (DM) production, nutrient uptake and removal, but do not result in the greatest yield due to the greater development of leaves and stems and the lower allocation of DM in storage roots.

2. Nitrogen fertilization increases significantly the proportion of $\mathrm{N}$ and $\mathrm{S}$ accumulated in stems, and of $\mathrm{Ca}, \mathrm{Mg}, \mathrm{Fe}$, and $\mathrm{Mn}$ in leaves.

3. $\mathrm{N}$ supply increases $\mathrm{Zn}$ distribution to stems and leaves, whereas high $\mathrm{N}$ rates increase $\mathrm{Cu}$ allocation to stems more than to the rootstock.

\section{Acknowledgments}

To Conselho Nacional de Desenvolvimento Científico e Tecnológico $(\mathrm{CNPq}$, process numbers 119742/2013-6 and 303073/2014-8), for scholarships awarded.

\section{References}

COELHO, F.S.; FONTES, P.C.R.; PUIATTI, M.; NEVES, J.C.L.; SILVA, M.C.C. Dose de nitrogênio associada à produtividade de batata e índices do estado de nitrogênio na folha. Revista Brasileira de Ciência do Solo, v.34, p.1175-1183, 2010. DOI: 10.1590/S0100-06832010000400017.

COSTA, G.P. da. Nutrição da cultura da mandioquinha-salsa. Horticultura Brasileira, v.18, p.250-252, 2000.

DEL VALLE JÚNIOR, R.; ORTIZ, C.E.; SANTIAGO-CORDOVA, M.A. Fertilization of arracacha in Ultissol. Journal of Agriculture of the University of Puerto Rico, v.79, p.183-185, 1995.

ECHER, F.R.; DOMINATO, J.C.; CRESTE, J.E. Absorção de nutrientes e distribuição da massa fresca e seca entre órgãos de batata-doce. Horticultura Brasileira, v.27, p.176-182, 2009. DOI: 10.1590/S0102-05362009000200010.

FERNANDES, A.M.; SORATTO, R.P.; SILVA, B.L. Extração e exportação de nutrientes em cultivares de batata: I Macronutrientes. Revista Brasileira de Ciência do Solo, v.35, p.2039-2056, 2011. DOI: 10.1590/S0100-06832011000600020.

FILGUEIRA, F.A.R. Novo manual de olericultura: agrotecnologia moderna na produção e comercialização de hortaliças. 3.ed. Viçosa: Ed. da UFV, 2008. 421p.

FURLANI, A.M.C.; FURLANI, P.R.; BATAGLIA, O.C.; HIROCE, R.; GALLO, J.R.; BERNARDI, J.B.; FORNASIER, J.B.; CAMPOS, H.R. Composição mineral de diversas hortaliças. Bragantia, v.37, p.33-44, 1978. DOI: 10.1590/S0006-87051978000100005.

GRACIANO, J.D.; HEREDIA ZÁRATE, N.A.; VIEIRA, M. do C.; ROSA, Y.B.C.J.; SEDIYAMA, M.A.N.; RODRIGUES, E.T. Efeito da cobertura do solo com cama-de-frango semidecomposta sobre dois clones de mandioquinha-salsa. Acta Scientiarum.
Agronomy, v.28, p.365-371, 2006. DOI: 10.4025/actasciagron. v28i3.957.

HEREDIA ZÁRATE, N.A.; VIEIRA, M. do C.; GRACIANO, J.D.; FIGUEIREDO, P.G.; BLANS, N.B.; CURIONI, B.M. Produtividade de mandioquinha-salsa sob diferentes densidades de plantio e tamanho das mudas. Ciência e Agrotecnologia, v.33, p.139-143, 2009. DOI: 10.1590/S1413-70542009000100020.

HEREDIA ZÁRATE, N.A.; VIEIRA, M. do C.; RECH, J.; QUAST, A.; PONTIM, B.C.Á.; GASSI, R.P. Yield and gross income of arracacha in monocrop and intercropping with the Japanese bunching onion and parsley. Horticultura Brasileira, v.26, p.287-291, 2008. DOI: 10.1590/S0102-05362008000200032.

LOPES, M.B.S.; SOUSA, S.A. de; NASCIMENTO, I.R. do; FIDELIS, R.R. Resposta de cultivares de arroz à adubação nitrogenada em solos arenosos de várzea tropical. Revista Verde, v.8, p.86-92, 2013.

MALAVOLTA, E.; VITTI, G.C.; OLIVEIRA, S.A. de. Avaliação do estado nutricional das plantas: princípios e aplicações. 2.ed. Piracicaba: Associação Brasileira para Pesquisa da Potassa e do Fosfato, 1997. 308p.

MESQUITA FILHO, M.V. de; SOUZA, A.F.; SILVA, H.R. de; SANTOS, F.F. dos; OLIVEIRA, A.S. de. Adubação nitrogenada e fosfatada para a produção comercializável de mandioquinha-salsa em Latossolo Vermelho-Amarelo. Horticultura Brasileira, v.14, p.211-215, 1996.

MONTEIRO, D.A.; PERESSIN, V.A. Mandioquinha. In: RAIJ, B. van; CANTARELLA, H.; QUAGGIO, J.A.; FURLANI, A.M.C. (Ed.). Recomendações de adubação e calagem para o Estado de São Paulo. 2.ed. rev. atual. Campinas: IAC, 1997. 285p. (IAC. Boletim técnico, 100).

NUNES, E.E.; VILAS BOAS, E.V. de B.; PICCOLI, R.H.; XISTO, A.L.R.P.; VILAS BOAS, B.M. Efeito de diferentes temperaturas na qualidade de mandioquinha-salsa minimamente processada. Horticultura Brasileira, v.28, p.311-315, 2010. DOI: 10.1590/ S0102-05362010000300012.

OLIVEIRA, A.P. de; MOURA, M.F. de; NOGUEIRA, D.H.; CHAGAS, N.G.; BRAZ, M. do S.S.; OLIVEIRA, M.R.T. de; BARBOSA, J.A. Produção de raízes de batata-doce em função do uso de doses de $\mathrm{N}$ aplicadas no solo e via foliar. Horticultura Brasileira, v.24, p.279-282, 2006. DOI: 10.1590/ S0102-05362006000300002.

OTSUBO, A.A.; BRITO, O.R.; MERCANTE, F.M.; OTSUBO, V.H.N.; GONÇALVES, M.A.; TELLES, T.S. Desempenho de cultivares elites de mandioca industrial em área de cerrado do Mato Grosso do Sul. Semina: Ciências Agrárias, v.30, p.1155-1162, 2009. DOI: 10.5433/1679-0359.2009v30n4Sup1p1155.

PÁDUA, J.G. de. Produção de batata e mandioquinha-salsa visando o processamento industrial. Revista Raízes e Amidos Tropicais, v.6, p.147-161, 2010.

PORTZ, A.; MARTINS, C.A.C.; LIMA, E. Crescimento e produção de raízes comercializáveis de mandioquinha-salsa em resposta à aplicação de nutrientes. Horticultura Brasileira, v.21, p.484-488, 2003. DOI: 10.1590/S0102-05362003000300014.

PORTZ, A.; MARTINS, C.A. da C.; LIMA, E.; ZONTA, E. Teores e acúmulo de nutrientes durante o ciclo da mandioquinha-salsa 
em função da aplicação de nitrogênio, fósforo e potássio. Horticultura Brasileira, v.24, p.329-333, 2006. DOI: 10.1590/ S0102-05362006000300012.

ROCHA, T.S.; DEMIATE, I.M.; FRANCO, C.M.L. Características estruturais e físico-químicas de amidos de mandioquinha-salsa (Arracacia xanthorrhiza). Ciência e Tecnologia de Alimentos, v.28, p.620-628, 2008. DOI: 10.1590/S0101-20612008000300018.

SANTOS, H.G. dos; JACOMINE, P.K.T.; ANJOS, L.H.C. dos; OLIVEIRA, V.A. de; OLIVEIRA, J.B. de; COELHO, M.R.; LUMBRERAS, J.F.; CUNHA, T.J.F. (Ed.). Sistema brasileiro de classificação de solos. 2.ed. Rio de Janeiro: Embrapa Solos, 2006. $306 \mathrm{p}$.

SEDIYAMA, M.A.N.; FREITAS, R.S. de; PEREIRA, P.C.; SEDIYAMA, T.; MASCARENHAS, M.H.T.; FERREIRA, F.A. Avaliação de herbicidas no controle de plantas daninhas em mandioquinha-salsa. Bragantia, v.67, p.921-926, 2008. DOI: 10.1590/S0006-87052008000400014.
SEDIYAMA, M.A.N.; SANTOS, M.R.; ALBANEZ, A.C.M.P.; RIBEIRO, J.M.O.; GRANATE, M.J.; VIDIGAL, S.M. Agrosilício na produção de clones de mandioquinha-salsa. Acta Scientiarum. Agronomy, v.31, p.427-432, 2009. DOI: 10.4025/actasciagron. v31i3.699.

SILVA, J.R. da; BLANCO, H.G.; NORMANHA, E.S.; FREIRE, E.S. Efeitos de doses crescentes de nitrogênio, fósforo e potássio sôbre a produção de mandioquinha-salsa. Bragantia, v.25, p.365-369, 1966. DOI: 10.1590/S0006-87051966000200008.

SOIL SURVEY STAFF. Keys to soil taxonomy. $11^{\text {th }}$ ed. Washington: United States Department of Agriculture, Natural Resources Conservation Service, 2010. 338p.

TORALES, E.P.; HEREDIA ZÁRATE, N.A.; VIEIRA, M. do C.; GASSI, R.P.; SALLES, N.A.; PINTO, J.V. da C. Influência da cama de frango e de espaçamentos entre plantas na produtividade agroeconômica de mandioquinha-salsa. Revista Ceres, v.61, p.162-171, 2014. DOI: 10.1590/ S0034-737X2014000200002.

Received on January 27, 2015 and accepted on June 5, 2015 